\title{
ADORA2B wt Allele
}

National Cancer Institute

\section{Source}

National Cancer Institute. ADORA2B wt Allele. NCI Thesaurus. Code C51398.

Human ADORA2B wild-type allele is located within 17p12-p11.2 and is approximately 31 $\mathrm{kb}$ in length. This allele, which encodes adenosine $\mathrm{A} 2 \mathrm{~b}$ receptor protein, plays a role in both the stimulation of adenylate cyclase activity in the presence of adenosine and axon elongation. 